\title{
PENGARUH AROMATERAPI LAVENDER TERHADAP PENURUNAN INSOMNIA PADA LANJUT USIA DI PANTI WERDHA GUNA BUDI BHAKTI MEDAN
}

\author{
Hartika Samgryce Siagian \\ Staf Pengajar Prodi S1 Farmasi STIKes Imelda Medan, Jalan Bilal Nomor 52 Medan \\ E-mail: hartikasiagian@gmail.com
}

\begin{abstract}
ABSTRAK
Insomnia adalah gejala kelainan dalam tidur berupa kesulitan berulang untuk tidur atau mempertahankan tidur walaupun ada kesempatan untuk tidur. Aromaterapi merupakan terapi dengan memakai minyak esensial yang ekstrak dan unsur kimianya diambil dengan utuh. Penelitian ini bertujuan untuk mengetahui pengaruh aroma terapi lavender terhadap penurunan insomnia pada lanjut usia. Penelitian dilakukan pada April 2017. Jenis penelitian ini adalah observasional, dengan cara pendekatan one group pretest-posttest. Populasi dalam penelitian ini lanjut usia penghuni Panti werdha Guna Budi Bhakti Medan yang berjumlah 62 orang dan sampel sebanyak 13 orang yang ditentukan dengan menggunakan teknik purposive sampling. Analisis statistik yang digunakan uji chi-square. Hasil analisis univariat, didapat bahwa mayoritas responden sebelum diberi aromaterapi mayoritas menderita insomnia sedang yaitu sebanyak 14 orang (93,33\%) dan minoritas menderita insomnia berat sebanyak 1 orang (6,67\%). Setelah diberi aromaterapi mayoritas responden mengalami insomnia ringan yaitu sebanyak 13 orang (86,67\%), sedangkan minoritas responden mengalami insomnia sedang yaitu sebanyak 2 orang (13,33\%). Hasil analisis bivariat menunjukkan bahwa sebelum diberi aromaterapi ada 14 orang reponden mengalami insomnia sedang dan 1 orang mengalami insomnia berat, sedangkan pada post test terjadi penurunan tingkat insomnia menjadi 13 orang insomnia ringan dan 2 orang insomnia sedang. Uji statistik Wilcoxon Signed Ranks Test diperoleh nilai probabilitas p 0,000 $<0,005$ yang berarti terdapat pengaruh aromaterapi terhadap penurunan tingkat insomnia pada lanjut usia. Disarankan bagi profesi keperawatan untuk mampu melanjutkan dan lebih meningkatkan terapi komplementer yang berguna untuk meningkatkan pelayanan keperawatan khususnya dalam keperawatan lanjut usia dan aromaterapi.
\end{abstract}

Kata kunci: Aromaterapi Lavender, Insomnia, Lanjut Usia.

\section{PENDAHULUAN}

Lanjut usia adalah keadaan yang ditandai oleh kegagalan seseorang untuk mempertahankan keseimbangan terhadap kondisi stres fisiologis. Kegagalan ini berkaitan dengan penurunan daya kemampuan untuk hidup serta peningkatan kepekaan secara individual. Efendi (2009), mengatakan seseorang dikatakan lanjut usia (lansia) apabila usianya 65 tahun ke atas. Lanjut usia bukan suatu penyakit, namun merupakan tahap lanjut dari suatu proses kehidupan yang ditandai dengan penurunan kemampuan tubuh untuk beradaptasi dengan stres lingkungan.

Lanjut usia mengalami penurunan efektifitas tidur pada malam hari $70 \%$ sampai $80 \%$ dibandingkan dengan usia muda. Presentase penderita insomnia lebih tinggi dialami oleh orang yang lebih tua, dimana 1 dari 4 pada usia 60 tahun atau lebih mengalami sulit tidur yang serius (Kurnia, 2009). Insomnia adalah gejala kelainan dalam tidur berupa kesulitan berulang untuk tidur atau mempertahankan tidur walaupun ada kesempatan untuk itu. Gejala tersebut biasanya diikuti gangguan fungsional saat bangun. Insomnia sering disebabkan oleh adanya suatu penyakit atau akibat adanya permasalahan psikologis. Dalam hal ini, bantuan medis atau psikologis akan diperlukan (Hariana, 2004; Susilo dan Wulandari, 2011).

Di Indonesia, prevalensi penderita insomnia diperkirakan mencapai $10 \%$, yang artinya dari total 238 juta penduduk Indonesia sekitar 23 juta jiwa diantaranya menderita insomnia (Medicastore 2010). Hasil penelitian Bandiyah (2009) pada 
kelompok lanjut usia 40 tahun dijumpai $7 \%$ kasus yang mengeluh mengenai masalah tidur. Hal yang sama dijumpai pada kelompok usia 70 tahun, sebanyak $22 \%$ mengeluhkan masalah tidur.

Pada usia lebih dari 50 tahun, angka kejadian insomnia sekitar 30\% (Siregar, 2011). Sebagian besar lansia mempunyai resiko tinggi mengalami gangguan tidur akibat berbagai faktor. Orang lanjut usia yang sehat sering mengalami perubahan pada pola tidurnya yaitu memerlukan waktu yang lama untuk dapat tidur. Proses patologis terkait usia dapat menyebabkan perubahan pola tidur. Carskadon \& Dement, (1994) melaporkan kurang lebih 40-50\% dari populasi usia lanjut menderita gangguan tidur. Tidur adalah perilaku penarikan diri secara terus menerus dan tidak berespon terhadap lingkungannya yang bersifat reversible.

Aromaterapi merupakan terapi dengan memakai minyak esensial yang ekstrak dan unsur kimianya diambil dengan utuh. Aromaterapi adalah bagian dari ilmu herbal (herbalism) (Poerwadi, 2006). Sedangkan menurut Sharma (2009) mengatakan aromaterapi berarti pengobatan menggunaka $\mathrm{n}$ wangi-wangian.

Lestari (2015), dari hasil penelitiannya menunjukan bahwa dari 15 responden, sebelum pemberian lavender aromatherapy seluruhnya mengalami insomnia sedang (100\%) dan setelah pemberian lavender aromatherapy hampir seluruh responden mengalami penurunan menjadi insomnia ringan sejumlah 14 responden (93,3\%). Artinya ada pengaruh pemberian lavender aromatherapy terhadap penurunan insomnia pada lanjut usia di UPT Panti Werdha Mojopahit Mojokerto.

Berdasarkan latar belakang di atas, penulis tertarik untuk meneliti tentang pengaruh aromaterapi lavender terhadap penurunan insomnia pada lanjut usia di Panti Werdha Guna Budi Bhakti Medan.

\section{METODE}

Jenis

penelitian ini adalah observasional, dengan cara pendekatan one group pretest-posttest. Rancangan ini dimaksudkan untuk mengukapkan pengaruh sebap akibat dengan cara melibatkan satu kelompok subjek. Kelompok subjek diobservasi sebelum intervensi, kemudian diobservasi lagi setelah intervensi.

Pengujian sebab akibat dilakukan dengan cara membandingkan hasil pra-tes dengan pasca tes. Dalam rancangan ini, kelompok sampel hanya terdiri dalam satu kelompok perlakuan yang kemudian diberikan pratest menggunakan kuesioner KSPBJ-IRS perlakuan (pemberian aromaterapi lavender selama 14 hari berturut-turut) dilakukan posttest dengan kuesioner yang sama. Sebelum mengisi instrumen, responden diminta kesediannya dan diberi inform consent. Kuesioner yang digunakan dalam penelitian ini adalah Kelompok Studi Psikiatri Biologik JakartaInsomnia Rating Scale (KSPBJ-IRS). KSPBJ-IRS digunakan untuk mengukur tingkat insomnia lanjut usia.

Analisa data dalam penelitian ini diawali dengan menggunakan uji frekuensi untuk data univariat. Sedangkan untuk mengetahui pengaruh aroma terapi lavender terhadap insomnia pada lanjut usia di panti Werdha Guna Budi Bhakti Medan, digunakan uji statistik Wilcoxon Signed Rank Tes.Instrumen yang digunakan dalam penelitian ini yaitu lembar dokumentasi dan lembar observasi yang berisikan data responden dan hasil pengamatan selama penelitian. Sebelum mengisi instrumen, responden diminta kesediannya dan diberi inform consent.

Kuesioner yang digunakan dalam penelitian ini adalah Kelompok Studi Psikiatri Biologik Jakarta-Insomnia Rating Scale (KSPBJ-IRS). KSPBJ-IRS digunakan untuk mengukur tingkat insomnia lanjut usia. Kuesioner KSPBJ-IRS berupa daftar pertanyaan mengenai kesulitan untuk memulai tidur, terbangun pada malam hari, terbangun lebih awal atau dini hari, merasa mengantuk pada siang hari, sakit kepala pada siang hari, merasa kurang puas 
terhadap tidur, merasa kurang nyaman atau gelisah saat tidur, mendapati mimpi buruk, badan terasa lemah, letih, kurang tenaga setelah tidur, jadwal jam tidur sampai bangun tidak beraturan, tidur selama enam jam dalam semalam.

Peneliti memilih KSPBJ-IRS sebagai instrumen penelitian dengan alasan bahwa instrumen KSPBJ-IRS memiliki pertanyaan yang lebih aplikatif bila digunakan pada lanjut usia. KSPBJ-IRS memiliki 11 pertanyaan yang dirasa tidak memberatkan lansia dalam menjawab dibanding kuesioner insomnia lainnya yang ditemukan peneliti seperti Pittsburg Sleep Quality Index (PSQI) yang terdapat banyak pertanyaan sehingga dirasa akan menyulitkan lanjut usia dalam menjawab pertanyaan kuesioner.

\section{HASIL}

Berdasarkan hasil penelitian, karakterist ik responden yaitu jenis kelamin dan kegiatan dipanti dapat dilihat dalam tabel di bawah ini.

Tabel 1. Distribusi Frekuensi Responden Berdasarkan Jenis Kelamin dan Kegitan Panti

\begin{tabular}{cccc}
\hline No & Jenis Kelamin & Frekuensi & $\mathbf{( \% )}$ \\
\hline 1 & Laki-laki & 12 & 80,00 \\
2 & Perempuan & 3 & 20,00 \\
& Total & $\mathbf{1 5}$ & $\mathbf{1 0 0}$ \\
No & Kegiatan & Frekuensi & $\mathbf{( \% )}$ \\
1 & Bekerja & 3 & 20,00 \\
2 & Tidak bekerja & 12 & 80,00 \\
& Total & $\mathbf{1 5}$ & $\mathbf{1 0 0}$ \\
\hline
\end{tabular}

Berdasarkan tabel di atas, diketahui bahwa mayoritas responden berjenis kelamin laki-laki yaitu sebanyak 12 orang $(80,00 \%)$, sedangkan minoritas berjenis kelamin perempuan yaitu sebanyak 3 orang $(20,00 \%)$. Berdasarkan kegiatan di panti, mayoritas responden tidak bekerja yaitu sebanyak 12 orang $(80,00 \%)$, minoritas bekerja yaitu sebanyak 3 orang $(20,00 \%)$.

\section{Tingkat Insomnia Pre Test}

Berdasarkan penelitian, tingkat insomnia pre test responden dapat dilihat pada tabel dibawah ini.

Tabel 2. Distribusi Frekuensi Responden Berdasarkan Tingkat Pinsomnia Pre Test

\begin{tabular}{clcc}
\hline No & $\begin{array}{c}\text { Insomnia } \\
\text { Pre Test }\end{array}$ & $\begin{array}{c}\text { Frekuensi } \\
\text { (Jumlah) }\end{array}$ & $\begin{array}{c}\text { Persentasi } \\
(\mathbf{\%})\end{array}$ \\
\hline 1 & Ringan & 0 & 0,0 \\
2 & Sedang & 14 & 93,33 \\
3 & Berat & 1 & 6,67 \\
\hline & Total & $\mathbf{1 5}$ & $\mathbf{1 0 0}$ \\
\hline
\end{tabular}

Berdasarkan tabel di atas, diketahui bahwa mayoritas responden sebelum diberi aromaterapi mayoritas menderita insomnia sedang yaitu sebanyak 14 orang $(93,33 \%)$ dan minoritas menderita insomnia berat sebanyak 1 orang $(6,67 \%)$.

\section{Tingkat Insomnia Post Test}

Berdasarkan penelitian, setelah diberi aromaterapi dapat dilihat pada tabel dibawah ini.

Tabel 3. Distribusi Frekuensi Responden Berdasarkan Tingkat Insomnia Post Test

\begin{tabular}{clcc}
\hline No & $\begin{array}{l}\text { Insomnia } \\
\text { Post Test }\end{array}$ & $\begin{array}{c}\text { Frekuensi } \\
\text { (Jumlah) }\end{array}$ & $\begin{array}{c}\text { Persentasi } \\
(\mathbf{\%})\end{array}$ \\
\hline 1 & Ringan & 13 & 86,67 \\
2 & Sedang & 2 & 13,33 \\
3 & Berat & 0 & 0 \\
\hline & Total & $\mathbf{1 5}$ & $\mathbf{1 0 0}$ \\
\hline
\end{tabular}

Berdasarkan tabel di atas, diketahui bahwa setelah diberi aromaterapi mayori tas responden mengalami insomnia ringa $\mathrm{n}$ yaitu sebanyak 13 orang $(86,67 \%)$, sedangkan minoritas responden mengala mi insomnia sedang yaitu sebanyak 2 orang $(13,33 \%)$.

\section{Pengaruh aroma terapi lavender terhada p penurunan insomnia pada lanjut usia}

Berdasarkan penelitian, pengaruh aroma terapi lavender terhadap penurunan insomnia pada lanjut usia dapat dilihat pada tabel dibawah ini. 
Tabel 4. Distribusi Frekuensi Pengaruh Aromaterapi terhadap Penurunan Insomnia

\begin{tabular}{lccc}
\hline $\begin{array}{c}\text { Tingkat } \\
\text { Insomnia }\end{array}$ & $\begin{array}{c}\text { Pre } \\
\text { test }\end{array}$ & $\begin{array}{c}\text { Post } \\
\text { test }\end{array}$ & $\mathbf{X}^{\mathbf{2}}$ \\
\hline Ringan & 0 & 13 & 0,000 \\
Sedang & 14 & 2 & \\
Berat & 1 & 0 & \\
$\quad$ Jumlah & $\mathbf{1 5}$ & $\mathbf{1 5}$ & \\
\hline
\end{tabular}

Berdasarkan tabel di atas, diketahui bahwa sebelum diberi aromaterapi ada 14 orang reponden mengalami insomnia sedang dan 1 orang mengalami insomnia berat, sedangkan pada post test terjadi penurunan tingkat insomnia menjadi 13 orang insomnia ringan dan 2 orang insomnia sedang. Uji statistik Wilcoxon Signed Ranks Test dipero leh nilai probabilitas $p 0,000<0,005$ yang berarti terdapat pengaruh aromaterapi terhadap penurunan tingkat insomnia pada lanjut usia.

\section{PEMBAHASAN}

Dilihat dari tabel 2 tentang insomnia pada lanjut usia sebelum pemberian lavender aromatherapy 14 responden $(93,3 \%)$ mengalami insomnia sedang dan 1 orang $(6,67 \%)$ mengalami insomnia berat. Lansia beresiko mengalami gangguan tidur yang disebabkan oleh banyak faktor misalnya pensiunan dan perubahan pola sosial, kematian pasangan hidup atau teman dekat, peningkatan penggunaan obat-obatan, penyakit yang dialami, gangguan mood, ansietas, kepercayaan terhadap tidur, dan perasaan negatif merupakan indikator terjadinya insomnia (Akoso dan Galuh, 2009).

Perubahan pola tidur lansia disebabkan perubahan system saraf pusat yang mempengaruhi pengaturan tidur (Saryono dan Widianti, 2011). Kualitas dan kuantitas tidur dipengaruhi oleh beberapa faktor. Kualitas tersebut dapat menunjukan adanya kemampuan individu untuk tidur dan memperoleh jumlah istirahat sesuai dengan kebutuhannya.

Insomnia dapat dialami oleh siapa saja, tidak terkecuali pada lansia. Proses tidur pada lansia dapat dipengaruhi oleh gangguan fisik, keteraturan waktu tidur, kenyamanan dan kecemasan saat tidur. Dari data yang diperoleh dari tabel 4.3 tentang insomnia pada lanjut usia setelah pemberian lavender aromatherapy didapatkan sebagian kecil responden berjumlah 2 orang $(13,33 \%)$ mengalami insomnia sedang dan hampir seluruh dari respon den berjumlah 14 orang $(86,67 \%)$ mengalami insomnia ringan. Hal ini menunjukkan bahwa ada penurunan dari insomnia sedang menjadi insomnia ringan.

\section{Lavender Aromatherapy sangat} bermanfaat untuk membantu serangan insomnia karena khasiat psikologi yang menenangkan yang diantaranya dapat mencairkan rasa marah yang tersimpan, menenangkan emosi yang tidak stabil, meringankan stress, mengatasi kepanikan, ketidak sabaran, menenangkan jiwa, mengurangi rasa ketagihan, memberikan rasa aman dan kenyamanan (Poerwadi, 2006). Aromatherapy merupakan terapi penyembuhan yang memanfaatkan sifat dan aroma minyak esensial. Meskipun kata "aroma" membuatnya seolah-olah minyak yang dihirup, Aromatherapy juga bisa meresap kedalam kulit (Ehrlich, 2009).

Insomnia dapat diatasi dengan cara non-farmakologi diantaranya dengan pemberian lavender aromatherapy yang mampu membantu lansia pada kondisi yang lebih tenang sehingga dapat mengontrol dan mengelola stressor yang mempengaruhi tingkat insomnia pada lanjut usia. Selain pemberian lavender aromatherapy ada cara lain untuk mengatasi masalah insomnia diantaranya latihan relaksasi pernapasan, senam ergonomis dan terapi air hangat.

Dari hasil analisa data dengan menggunakan wilcoxon sign testdengan taraf signifikan $\alpha=0,05$ diperoleh hasil perhitungan $\rho=0,000<\alpha=0,05$ dengan demikian Ho ditolak dan $\mathrm{H} 1$ diterima. Artinya ada pengaruh pemberian lavender aromatherapy terhadap penurunan insomnia pada lanjut usia. Berdasarkan data yang diperoleh diatas, maka terdapat kesesuaian dengan teori yang menyatakan bahwa Aromatherapy adalah bagian dari ilmu herbal (herbalism). Manfaat minyak esensial 
untuk keseimbangan fisik dan mental sangatlah luar biasa. Aroma dan kelembutan minyak esensial dapat mengatasi keluhan fisik dan psikis. Banyak cara yang dapat digunakan untuk menanggulangi masalah tidur. Salah satunya adalah terapi relaksasi yang termasuk terapi non-farmakologi. Terapi relaksasi dapat dilakukan untuk jangka waktu yang terbatas dan biasanya tidak memiliki efek samping. Aromaterapi merupakan salah satu bentuk terapi relaksasi. Aromaterapi merupakan proses penyembuhan kuno yang menggunakan sari tumbuhan aromaterapi murni yang bertujuan untuk meningkatkan kesehatan dan kesejahteraan tubuh, pikiran dan jiwa (Poerwadi, 2006)

\section{KESIMPULAN}

Dari hasil penelitian pengaruh aromaterapi lavender terhadap penurunan insomnia pada lanjut usia di Panti Werdha Guna Budi Bhakti Medan, maka diperoleh kesimpulan sebagai berikut:

1. Mayoritas responden sebelum diberi aromaterapi mayoritas menderita insomnia sedang yaitu sebanyak 14 orang $(93,33 \%)$ dan minoritas menderita insomnia berat sebanyak 1 orang $(6,67 \%)$.

2. Setelah diberi aromaterapi mayoritas responden mengalami insomnia ringan yaitu sebanyak 13 orang $(86,67 \%)$, sedangkan minoritas responden mengalami insomnia sedang yaitu sebanyak 2 orang $(13,33 \%)$.

3. Sebelum diberi aromaterapi ada 14 orang reponden mengalami insomnia sedang dan 1 orang mengalami insomnia berat, sedangkan pada post test terjadi penurunan tingkat insomnia menjadi 13 orang insomnia ringan dan 2 orang insomnia sedang. Uji statistik Wilcoxon Signed Ranks Test diperoleh nilai probabilitas $p 0,000<0,005$ yang berarti terdapat pengaruh aromaterapi terhadap penurunan tingkat insomnia pada lanjut usia.

\section{SARAN}

1. Bagi profesi Keperawatan

Mampu melanjutkan dan lebih meningkatkan terapi komplementer yang berguna untuk meningkatkan pelayanan keperawatan khususnya dalam keperawatan lanjut usia dan aromaterapi

2. Bagi institusi

Mengembangkan kurikulum dan meningkatkan peran pendidik dalam menyampaikan pengetahuan tentang keperawatan komplementer khususnya aromaterapi bagi mahasiswa secara lebih menarik sehingga mampu mening katkan pengetahuan dan ketrampilan dalam mengaplikasikannya.

3. Bagi masyarakat

Meningkatkan pengetahuan tentang terapi komplementer serta mampu mengaplikasikannya dalam kehidupan sehari-hari.

\section{DAFTAR PUSTAKA}

Adiyati, S. Pengaruh Aromaterapi terhadap Insomnia pada Lansia di PSTW Unit.

Akso, Galuh. (2009). Bebas Insomnia. Yogyakarta: Kanisus.

Anggota IKAPI. (2004). Insomnia dan Gangguan Tidur Lainnya. Jakarta: Alex Media Komputindo.

Anggraini, dkk. (2009). Aromaterapi Bunga Lavender Memperbaiki Kualitas.

Ariani. (2012). Pengaruh Pemberian Aromaterapi Cendana terhadap Kualitas Tidur Remaja di Panti Asuhan Dharma Jati II Denpasar Tahun 2012.

Azizah, Ulik. (2011). Keperawatan Lanjut Usia. Yogyakarta: Graha Ilmu.

Bandiyah, S. (2009). Lanjut Usia dan Keperawatan Gerontik. Yogyakarta: Nuha Medika.

Dewi, P. (2013). Aromaterapi Lavender sebagai Media Relaksasi. Jurnal Bagian Farmasi Fakultas Kedokteran Universit as Udayana. 
Fatimah. (2010). Merawat Lanjut Usia Suatu Pendekatan Proses Keperawatan Gerontik. Jakarta: Trans Info Media.

Green, W. (2009). 50 Hal Yang Bisa Anda Lakukan Hari Ini untuk Mengatasi Insomnia. Jakarta: Elex Media Komputindo.

Hariana, A. (2004). 812 Resep untuk Mengobati 236 Penyakit. Jakarta: Pustaka Populer Obor.

Hidayat, A. Aziz. (2006). Kebutuhan Dasar Manusia, Aplikasi konsep dan Proses Keperawatan. Jakarta: Salemba Medik.

Iwan. (2009). Skala Insomnia (KSPBJ Insomnia Rating Scale).

Jaelani. (2009). Aromatherapi. Jakarta: Rineka Cipta.

Kristanti, E. (2010). Pengaruh Aromaterapi Lavender terhadap Penurunan Derajat Kecemasan pada Lansia di Panti Wredha ST. Yoseph Kediri. Jurnal STIKES RS Baptis Kediri.

Kurnia, A. (2009). Lavender Aromatherapy Improve Quality of Sleep in Eldery People.

Kusnanto, dkk. (2007). Manfaat Aromaterap $i$ Lavender terhadap Penurunan Insomnia.

Maryam R. Siti, dkk. (2008). Mengenal Usia Lanjut dan Perawatan Nya. Jakarta: Salemba Medika.

Maryani, Suharmiati. (2003). Tanaman Obat untuk Mengatasi Penyakit pada Usia Lanjut. Jakarta: Agromedia Pustaka.
Murwani Arita, Priyantari Wiwin. (2011). Gerontik Keperawatan Dasar Dan Asuhan Keperawatan Home Care dan Komunitas. Jakarta: Fitramaya.

Nugroho wahjudi. (2006). Keperawatan Gerontik \& Geriatrik. Jakarta: EGC.

Nursalam. (2011). Konsep dan Penerapan Metodelogi Penelitian Ilmu Keperawat an. Jakarta: Salemba Medika.

Padila. (2013). Buku Ajar Keperawatan Gerontik. Yogyakarta: Nuha Medika.

Panti Tresna Werda Ilomata Gorontalo. (2013). Daftar Nama-Nama Penghuni PSTW "Ilomata" Kota Gorontalo.

Poerwadi. (2006). Aromaterapi Sahabat Calon Ibu. Jakatra: Dian Rakyat.

Price. (1997). Aromaterapi bagi Profesi Kesehatan. Jakarta: EGC.

Riyanto, A. (2011). Aplikasi Metodologi Kesehatan. Yogyakarta: Nuha Medika.

Saryono, Widianti. (2011). Kebutuhan Dasar Manusia. Yogyakarta: Nuha Medika.

Siregar, M. (2011). Mengenal Sebab-Sebab, Akibat-Akibat, dan Cara Terapi Insomnia. Jakarta: Flash Books.

Sugiono. (2013). Statistik Nonparametris untuk Penelitian. Bandung: Alfabeta.

Susilo, Wulandari. (2011). Cara Jitu Mengatasi Insomnia. Yogyakarta: Andi Offset.

Utama, Hendra. (2004). Geriatri Ilmu Kesehatan Usia Lanjut. Jakarta: FKUI. 